\title{
ISRAEL AND THE NATIONS: AN ESSAY IN BIBLICAL THEOLOGY
}

\author{
Charles H.H. Scobie
}

\begin{abstract}
Summary
The theme of the relation of God's chosen people Israel to the other nations of humankind constitutes a test case for 'Biblical Theology': is it possible to produce a synthesis of the apparently diverse Old Testament and New Testament materials? Israel relates to other peoples in the Old Testament in two ways: historically, through incorporation, and eschatologically, through the ingathering of the Gentiles. It is the Old Testament eschatological expectation which provides the clue to understanding the New Testament theology of mission to the Gentiles, as with the Christ Event the new age is inaugurated. This approach is illustrated through study of the Old Testament theme of 'The Tribute of the Nations' in three New Testament books.
\end{abstract}

\section{Introduction}

The subject of 'Biblical Theology' continues to attract attention and discussion. 1 I have tried to make a case for Biblical Theology as an intermediate or bridge discipline which would assume and accept the fruits of historical-critical study of the Bible, but go on to undertake some kind of synthesis of the biblical material, which would mediate the results of specialised biblical studies to those who use the Bible in dogmatics, in ethics, and in the life and work of the Christian community generally. ${ }^{2}$ Such a Biblical Theology would be 'canonical' in the sense that it would be concerned with both Old and New Testaments, would be based primarily on the final canonical form of Scripture, and would deal with the full range of canonical materials. It would seek to locate major overarching themes in the biblical material and identify underlying structures, while taking the greatest care not to

1See The Promise and Practice of Biblical Theology, J. Reumann (ed.), (Minneapolis, Fortress 1991).

${ }^{2}$ C.H.H. Scobie, 'The Challenge of Biblical Theology', TynB 42 (1991) 3161; 'The Structure of Biblical Theology', TynB 42 (1991) 163-94; New Directions in Biblical Theology', Themelios 17.2 (1992) 4-8. 
impose a structure which is alien to the material. It would seek an underlying unity without obliterating the rich diversity.

The theme of the relation of God's chosen people Israel to the other nations of humankind constitutes a test case and a major challenge to any would-be biblical theologian. In the Old Testament Israel is a national group, while in the New Testament Christianity is a universal religion; how can such diverse Old Testament and New Testament materials be synthesised? Not only so, we are dealing here with a classic case of the question, 'Who was the real founder of Christianity, Jesus or Paul?' Are their attitudes not totally at odds? Finally, even within the New Testament itself, are the views of e.g. Paul and John on the question of mission not so diverse that we can only talk of 'New Testament theologies'? Within the limits of a single article these questions can only be addressed in broad outline. 3

\section{Israel and the Nations in the Old Testament}

Old Testament Theology has tended to concentrate on Heilsgeschichte, on the proclamation of 'the God who acts', in history, in relation to his chosen people Israel. But the Old Testament equally proclaims that God's presence and activity are to be seen in the whole created order, in the universe which he has made, and in relation to all the peoples of the earth. ${ }^{4}$

${ }^{3}$ On the Biblical Theology of mission see W. Manson, The Biblical Doctrine of Mission, IRM 42 (1953) 257-67; P. May, 'Towards a Biblical Theology of Missions', The Indian Journal of Theology 8 (1959) 21-8; G.W. Peters, A Biblical Theology of Missions (Chicago, Moody 1972); J.H. Kane, Christian Missions in Biblical Perspective (Grand Rapids, Baker 1976); D. Senior, C. Stuhlmueller, The Biblical Foundations for Mission (Grand Rapids, Eerdmans 1983); R.E. Hedlund, The Mission of the Church in the World (Grand Rapids, Baker 1991).

${ }^{4}$ Studies on the theme of mission in the Old Testament include H.H. Rowley, The Missionary Message of the Old Testament (London, Carey Kingsgate 1945); J. Hempel, 'Die Wurzeln des Missionswillens im Glauben des Alten Testaments', ZAW 66 (1954) 244-72; R. MartinAchard, Israël et les nations. La perspective missionaire de l'Ancien Testament (Neuchâtel, Delachaux 1959), ET A Light to the Nations: $A$ Study of the Old Testament Concept of Israel's Mission to the World (Edinburgh, Oliver and Boyd 1962); G.E. Wright, 'The Old Testament Basis for the Christian Mission', in The Theology of the Christian Mission, G.H. Anderson (ed.), (New York, McGraw-Hill 1961) 17-30; R. Dobbie, The Biblical Foundation of the Mission of the Church - I. Old 
It is highly significant that in the final canonical shape of Scripture, the focus in the first eleven chapters of Genesis is on the created order, on the origins and prehistory of all humankind. The call of Abram in Genesis 12 is related to God's dealings with the nations and is placed specifically in the context of the disintegration of human society and the dispersion of the nations in Genesis 11.5 The canon ends, in Revelation, with a book in which God's purposes are equally related to the whole created order, so that concern for people of 'every nation and tribe and tongue and people' (Rev. 14:6) forms a grand envelope structure framing the entire story of Scripture.

If, with the call of Abram, the focus in the Old Testament shifts to God's election of and dealings with a chosen people, nevertheless the concern for the entire created order is never lost sight of. It continually resurfaces-in the Psalms, 6 in Deutero-Isaiah, and, as much recent work in Biblical Theology has reminded us, in the Wisdom literature. ${ }^{7}$ Attention has often been called to the 'universal', or at least potentially universal elements in Israel's faith. Belief in one God before whom the gods of the nations are as nothing, in a God who is the creator of the entire universe, in a God whose moral law is binding on all humankind-these constantly express a concern not only with the people of Israel but with all nations of the earth. 8

Moreover, at least at some key points in the Old Testament the call of Israel is related to the nations. In the same text in which God promises Abram 'I will make of you a great nation', God also says, 'In you shall all the families of the

Testament', IRM 51 (1962) 196-205; J. Blauw, The Missionary Nature of the Church (New York, McGraw-Hill 1962), chs. 1-3; A. Rétif, P. Lamarche, The Salvation of the Gentiles and the Prophets (Montreal, Palm 1966); A.H. Lewis, 'Jehovah's International Love', JETS 15 (1972) 87-92.

${ }^{5}$ Cf. J. Blauw, op. cit., 19, 20.

6 See D. Senior, C. Stuhlmueller, op. cit., ch. 5, 'Israel's Prayer and Universal Mission'.

7See C.H.H. Scobie, 'The Place of Wisdom in Biblical Theology', BTB 14 (1984) 43-8.

${ }^{8}$ Cf. R. Dobbie, op. cit. D. Senior, C. Stuhlmueller, op. cit., 318, emphasise in this context 'a strong interaction between the community of Israel and secular culture and events.' 
earth be blessed' (Gn. 12:2,3). This text may have originally meant 'by you all the families of the earth shall bless themselves' (RSV), but it certainly came to be understood as meaning that through Abraham (and his descendants) God's blessing would be channelled to all mankind. 9 'It is particularly significant that the story of Abraham was thus from the beginning directed towards universal salvation. It was to give its true meaning to the call of Abraham and the choice of Israel, which can only be understood as part of the complete plan intended by Yahweh: the salvation of all'.10 The clearest expression of this viewpoint is found in Isaiah where God says to his servant Israel, 'I will give you as a light to the nations, that my salvation may reach to the end of the earth' (Is. 49:6, cf. v. 3; cf. also Is. 42:6).

Yet these texts become problematic in the light of the almost total absence from the Old Testament of any concern that the people of Israel should actively go out and share their knowledge of the one true God with the other nations of mankind.11

Broadly speaking Israel relates to other peoples in the Old Testament in two ways: historically, through incorporation and eschatologically through ingathering.

\section{The Historical Solution: Incorporation}

Although in the Old Testament Israel is presented as comprised of the descendants of the twelve sons of Jacob/Israel it is clear that at most stages of Israel's history provision was made for the incorporation of people of non-Israelite descent. Whatever view we take historically regarding the formation of the Israelite confederation, the canonical text provides ample evidence of incorporation, from the 'mixed multitude' which accompanied Israel out of Egypt (Ex. 12:38), to the adoption of Rahab and her family (Jos. 6:25), to the undoubted acceptance of foreigners within the kingdom of David (2 Sam. 11:3; 15:19-

${ }^{9}$ See the LXX of Gn. 12:3; Sirach 44:21; Acts 3:25; Gal. 3:8. Cf. A Rétif, P. Lamarche, op. cit., 21-2; J. Muilenberg, 'Abraham and the Nations: Blessing and World History', Int 19 (1965) 387-98.

${ }^{10}$ A. Rétif, P. Lamarche, op. cit., 22.

${ }^{11}$ The Book of Jonah is a striking example of the universal strand in the Old Testament but it is doubtful whether it was intended to be read as a call to mission. Cf. J. Blauw, op. cit., 33-4. 
23). The legislation of the Torah shows a special concern for the $g \bar{e}$ r, the stranger or sojourner, who for whatever reason is resident within Israel. In the late Old Testament period the concept of the gēr developed into that of the prosēlyte. The Septuagint translates $g \vec{e} r$ as proselytos, literally 'one who approaches' or 'draws near'.12 Attitudes towards proselytising varied considerably. ${ }^{13}$ The general consensus that there was a lively Jewish mission in the Second Temple period has been challenged in the recent work of Scot McKnight who argues that while there may have been a few Jewish evangelists, 'there is no evidence that could lead to the conclusion that Judaism was a "missionary religion" in the sense of aggressive attempts to convert Gentiles. ..' The predominant means of conversion appear to have been the life and example of individual Jews. ${ }^{14}$ Proselytes mentioned in the New Testament significantly are all associated with the Diaspora (Mt. 23:15; Acts $2: 10 ; 6: 5 ; 13: 43)$; generally distinguished from them are the sebomenoi ton theon, the 'God-fearers', who attached themselves to synagogues but did not accept circumcision or the full requirements of the ritual law. 15

There is an unmistakable tension within the canonical material regarding incorporation especially in relation to intermarriage. In the post-exilic period Nehemiah forbade intermarriage with foreigners such as Moabites (Ne. 13:23-7), while Ezra went further and broke up mixed marriages (Ezr.

${ }^{12}$ On proselytism see W.G. Braude, Jewish Proselytizing in the First Five Centuries of the Common Era (Providence RI, Brown University Press 1940); K.G. Kuhn, 'Proselytos', TWNT VI, (1968) 727-45; M.H. Pope, Proselyte', IDB 3 (1962) 921-31; S. McKnight, A Light Among the Gentiles: Jewish Missionary Activity in the Second Temple Period (Minneapolis, Fortress 1990).

${ }^{13} \mathrm{~F}$. Hahn, Mission in the New Testament (London, SCM 1965) rightly notes the absence of any evidence of winning over and converting Gentiles in the apocalyptic literature or in the Qumran writings. The rabbinic literature displays quite diverse attitudes: see J. Jeremias, Jesus' Promise to the Nations (London, SCM 1958) 16-7; K.G. Kuhn, op. cit., 737-8.

14S. McKnight, op. cit., 117.

${ }^{15}$ There has been vigorous discussion of the 'God-fearers' in recent years; see S. McKnight, op. cit., 156, n. 49 for bibliographical references. McKnight holds that there were various levels of attachment of Gentiles to Judaism, and that the category of 'God-fearer' 'exists whether the term is technical or not' (113). 
$9,10)$. In some historical circumstances the desire to maintain purity and avoid contamination of the faith seems to have predominated. 16 Yet the classic case of incorporation is Ruth, who, as the reader is constantly reminded is a foreigner, indeed a Moabitess. Ruth 4:13-22, it can be maintained, gives one of the main keys to the book: Ruth is not only incorporated into Israel, she is the great-grandmother of King David. It is difficult not to see here some polemic, if not against the policies of Ezra and Nehemiah, then against the legislation of Deuteronomy 23:3 which forbids anyone of Moabite descent, even to the tenth generation, from entering the assembly of the Lord, 17 a provision which would have disqualified King David himself!18

While historically, incorporation into Israel was always possible, in practice it had severe limitations. It was certainly limited in scale and at times severely limited by a countervailing exclusivist tendency. The basic concept is of certain individuals coming to Israel ( $c f$. the meaning of proselytos). With some exceptions around the New Testament period there was little or no thought of reaching out and actively seeking proselytes. And proselytism meant of course naturalisation, becoming a Jew. As McKnight says, 'Proselytization is resocialization or nationalization' ${ }^{19}$

\section{The Eschatological Solution: Ingathering}

A different way of relating Israel to the nations is found in Old Testament eschatological expectation. Here it is part of a broader pattern. Eschatology developed in the context of the sad realities of history. Called to be God's people in the world,

16See D. Bossmann, 'Ezra's Marriage Reform: Israel Redefined', BTB 9 (1979) 32-8.

17The prohibition of Dt. 23:3 was considerably modified in rabbinic Judaism. See W.G. Braude, op. cit., 49-57.

${ }^{18} \mathrm{~A}$ recent trend is to ascribe the Book of Ruth to the time of Solomon. See R. Hals, Theology of the Book of Ruth (Philadelphia, Fortress 1969); R.L. Hubbard, The Book of Ruth, NICOT (Grand Rapids, Eerdmans 1988). Hubbard does recognise that 'an important, though minor, theme is the acceptance of foreigners into Israelite society. Obviously, the career of Ruth offers the classical case study. . .In essence, the writer stresses that foreigners who live out the Israelite ideal of hesed toward Yahweh and toward Israel merit inclusion' (41).

${ }^{19}$ S. McKnight, op. cit., 47. 
the history of Israel was marked internally by disobedience and by division, and externally, from the eighth century onwards by subjection to one foreign nation after another. In a seemingly hopeless situation, hope was increasingly centred on the future action of God. The proclamation of what God had done in the past was matched by the promise of what he would do in the future. While these eschatological expectations are not presented in any systematic way, even within the oracles of a single prophetic book, certain major recurring themes stand out in clear relief.

(1) There is the hope of the reconstitution and the revival of Israel. With the Diaspora in view, this can involve the literal regathering of the tribes of Israel: 'Lo, these shall come from afar, and lo, these from the north and from the west. . (Is. 49:12). With this of course must come a restoration of their relationship with God. In the extended allegory of Ezekiel 34 God promises to rescue his sheep (v. 10) and to reconstitute the flock: 'As a shepherd seeks out his flock when some of his sheep have been scattered abroad, so will I seek out my sheep. . .And I will bring them out from the peoples. . . and will bring them into their own land. . I myself will be the shepherd of the sheep' (vv. 12, 13, 15).

(2) In the light of the tragic and unhealed division of God's people into North and South another focus of eschatological expectation is the reunion of God's people.20 Jeremiah's new covenant will be with the house of Israel and with the house of Judah (Je. 31:31). Ezekiel dramatises the reunion in his Oracle of the Two Sticks which are joined together so that Israel 'shall be no longer two nations' (Ezk. 37:15-23); and he visualises it in his picture of the ideal community with all twelve tribes having equal portions in a restored Israel (Ezk. 47:15-48:29).

(3) It is in this context that we are to view the eschatological expectation of the ingathering of the Gentiles.21 Clearly the

${ }^{20}$ See more fully C.H.H. Scobie, North and South: Tension and Reconciliation in Biblical History', in Biblical Studies in Honour of William Barclay J.R. McKay, J.F. Miller (eds.), (London, Collins 1976) 87-98, esp. 90-3.

${ }^{21}$ See H.H. Rowley, op. cit., ch. II, 'Visions of the Goal'; J. Jeremias, Jesus' Promise to the Nations (London, SCM 1958) 57-60. This expectation is found primarily in Isaiah (especially Deutero-Isaiah), Psalms, and Zechariah; nevertheless, it constitutes an important strand in OT eschatological expectation. 
basic principle of one set of passages is that of eschatological reversal. Where is Israel's God when again and again she has to submit to foreign domination? At the eschaton, Israel shall receive the homage of the nations:

The sons of those who oppressed you shall come bending low to you; and all who despised you shall bow down at your feet. . (Is. 60:14)

One thinks of the image of King Jehu on the Black Obelisk (in the British Museum) licking the boots of Shalmaneser III; in God's future, the first shall be last, and the last shall be first. Some passages even envisage the nations serving Israel: 'Aliens shall stand and feed your flocks, foreigners shall be your ploughmen and vinedressers.' (Is. 61.5). A related theme is that of the tribute of the nations, again a reversal of the situation in which Israel frequently had to pay tribute to foreign nations. In the new age,

Nations shall come to your light, and kings to the brightness of your rising. . .the wealth of nations shall come to you. . They shall bring gold and frankincense, and shall proclaim the praise of the Lord. (Is. 60:3,5,6)

In another set of passages the more nationalistic overtones fade into the background and higher motives are adduced for the eschatological pilgrimage of the nations. They will come to learn about God and his Torah:

It shall come to pass in the latter days that the mountain of the house of the LORD. . shall be raised above the hills; and all nations shall flow to it, and many peoples shall come and say, Come, let us go up to the mountain of the LORD. . .that he may teach us his ways and that we may walk in his paths. . (Is. 2:2,3; cf. Mi. 4:1,2).22

Other texts envisage the worship of the nations:

All the ends of the earth shall remember and turn to the LORD; and all the families of nations shall worship before him. (Ps. 22:27)

Pointing out that the universal and eschatological vision of Psalm 22:27-31 depicts the worship and praise of all nations poured out to Yahweh', W.R. Hogg contends that this passage

22See the discussion of this passage in R. Martin-Achard, ET op. cit., ch. IV. 
'reflects Deutero-Isaiah's emphasis upon the universal kingdom of God'.23

And the foreigners who join themselves to the LORD. . . these will I bring to my holy mountain and make them joyful in my house of prayer. . .for my house shall be called a house of prayer for all peoples. (Is. 56:6,7) 24

The climax of this development is found in those passages which envisage the acceptance of Gentiles into God's people and in fact the salvation of the nations:

And many nations shall join themselves to the LORD in that day, and shall be my people. . .(Zc. 2:11)

Turn to me and be saved, all the ends of the earth!. . By myself I have sworn, from my mouth has gone forth in righteousness a word that shall not return: 'To me every knee shall bow, every tongue shall swear.' (Is. 45:22,23).

It is in this context of eschatological promise that God's concern for Israel (in the historical order) and for all mankind (in the created order) truly come together.

Despite this remarkable set of passages the fact remains that there is no real indication of any active missionary outreach on the part of Israel in the Old Testament period. This is so for three important, interlocking reasons.

(1) Firstly, the ingathering of the nations is an eschatological event. It is something which will happen 'in the latter days', or in the more abbreviated formulae, 'in that day' or 'at that time'; frequently the eschatological setting is presupposed by the context. Thus the Gentiles will be fully accepted, but not in the present; this is an event which belongs to God's future.

(2) Secondly, the ingathering of the nations is not the work of Israel. Frequently it is the nations themselves who will take the initiative. In a number of significant passages it is God who gathers in the nations. Thus in Isaiah it is God who says of 'the foreigners who join themselves to the Lord',

${ }^{23}$ W.R. Hogg, 'Psalm 22 and Christian mission: a reflection', IRM 77 (1988) 244.

${ }^{24} \mathrm{Cf}$. the striking passage in $1 \mathrm{Ki} .8: 41-3$, in Solomon's prayer at the dedication of the Temple, which exhibits a similar attitude to foreigners, but in an historical rather than an eschatological context.

See A. Rétif, P. Lamarche, op. cit., 44-5. 
These will I bring to my holy mountain and make them joyful in my house of prayer (Is. 56:6,7).

In Zechariah 8:20-3 Israel does play a mediating role ('In those days ten men from the nations of every tongue shall take hold of the robe of a Jew, saying, Let us go with you, for we have heard that God is with you'), but the situation is still one in which 'many peoples and strong nations shall come to seek the LORD of hosts in Jerusalem'.

(3) Thirdly, these prophetic passages all envisage the nations coming to Israel, not Israel going to the nations. The recurring verb is 'come': 'They will come to you. . .' (Mi. 7:12), 'nations shall come ...' (Is. 60:3), etc. This movement from the periphery to the centre has been appropriately labelled 'centripetal'. The goal of the eschatological ingathering of the nations is Jerusalem/Mount Zion/my holy mountain/the Temple.

\section{Jesus and the Nations}

An understanding of these two basic Old Testament approaches, historical incorporation and eschatological ingathering, is essential for an understanding of the relationship between Israel and the nations in the New Testament. 25

While the missionary outreach and rapid growth of the early Christian church is an undoubted fact of history, attested in Roman authors as well as in Christian writings, the attitude of Jesus himself to a Gentile mission has been the subject of endless dispute. ${ }^{26}$ It is well known that Jesus' one reference to Jewish proselytising is a highly negative one (Mt. 23:15).27

${ }^{25}$ Studies of the theme of mission in the NT include J. Jeremias, op. cit., R. Dobbie, The Biblical Foundation of the Mission of the Church - II. The New Testament', IRM 51 (1962) 281-90; F. Hahn, op. cit.; M. Hengel, 'Die Ursprünge der christlichen Mission', NTS 18 (1971-2) 15-38; B.F. Meyer, 'The World Mission and the Emergent Realization of Christian Identity', in Critical Realism and the New Testament (Allison Park PA, Pickwick 1989) 173-94.

${ }^{26}$ See the summaries in B. Sundkler, 'Jésus et les paiens', RHPR 16 (1936) 463-70; and F. Hahn, op. cit., 26-8. On Jesus' attitude see also D.W. Allen, 'Christ's Teaching About Missions', IRM 48 (1959) 157-67; T.W. Manson, Only to the House of Israel? Jesus and the Non-Jews (Philadelphia, Fortress 1964).

27J. Jeremias, op. cit., 17-18, advances strong arguments for the authenticity of this saying. 
Attention has often been called to universal elements in Jesus' teaching, ${ }^{28}$ and certainly he disassociated himself from narrow and nationalistic trends. ${ }^{29}$ However although all the Evangelists in their own way anticipate a future Gentile mission it seems clear that Jesus himself restricted his mission and that of his disciples to the people of Israel: 'Go nowhere among the Gentiles, and enter no town of the Samaritans, but go rather to the lost sheep of the house of Israel' (Mt. 10:5,6; cf. Mt. 15:24).30 This is rather strikingly confirmed by Paul when he remarks in Romans 15:8 that Christ became 'a servant to the circumcised'. Clearly Jesus saw his ministry primarily in terms of the reconstitution and revival of Israel; he fulfils the role of the eschatological shepherd of Ezekiel 34 (cf. Mk. 6:34; Jn. 10:118), and appoints the Twelve (Mt. 10:1-4) as representatives of the reconstituted Israel. 31

It is of the first importance, however, that Christ proclaimed the entry of the Gentiles into the kingdom, and the complete equality of Gentiles as an eschatological concept. 'I tell you many will come from east and west and sit at table with Abraham, Isaac and Jacob in the kingdom of heaven, while the sons of the kingdom will be thrown into outer darkness. ..' (Mt. 8:11,12; Lk. 13:29 has 'men will come from east and west, and from north and south, and sit at table in the kingdom of God'.) Jews and Gentiles are placed on a completely even footing in regard to the eschatological events of the resurrection and judgment (Mt. 11:21-4, cf. Lk. 10:13-5; Mt. 12:41,42 par. Lk. 11:31,32: Mt. 25:32). Jesus' cleansing of the Temple, specifically of the Court of the Gentiles, is to be seen in this context. This was no mere act of a reformer as the reference to Jeremiah 7:11 might suggest (Mk. 11:17b). Rather,

${ }^{28} \mathrm{~A}$. Harnack, The Expansion of Christianity in the First Three Centuries, I (London, Williams \& Norgate 1904) 48 , contends that 'the local and temporal traits' in Jesus' teaching tended to be forgotten, while people found in his message 'a vital love of God and men, which may be described as implicit universalism'. A similar view is found in M. Goguel, 'Jésus et les origines de l'universalisme chrétien', RHPR 12 (1932) 193-211.

${ }^{29} \mathrm{Cf}$. J. Jeremias, op. cit., 41-6.

${ }^{30} \mathrm{Cf}$. D.W. Allen, op. cit., 157-9.

${ }^{31} \mathrm{M}$. Hengel, op. cit., 36, contends that Jesus' calling and sending out of his disciples constitutes the true starting point of the early Christian mission, and on this basis designates Jesus as the 'Urmissionar'. 
as the clear reference to the eschatological ingathering of the Gentiles shows (Mk. 11:17a, 'My house shall be called a house of prayer for all the nations' $=$ Is. 56:7) it is to be seen in the light of the Temple Saying of Mark 14:58 par. Matthew 26:61 par. John 2:19 as preparing the way for the New Temple in which the people of God will worship at the eschaton, in the worship of which the Gentiles will fully share.32

It is necessary to go one step beyond this, however, and note that since for Jesus the new order is not only future, but also breaking in now, in his own words and deeds, Jesus does on occasion accept Gentiles as well as Jews, and give them a share in the dawning salvation. ${ }^{33}$ When a Gentile army officer sought healing for his servant, Jesus not only complied but commented, 'Truly, I say to you, not even in Israel have I found such faith' (Mt. 8:10 par. Lk. 7:9; in Mt. 8:11 this is the setting for the reference to the ingathering of the Gentiles). Similarly, after testing the faith of the Syrophoenician woman, Jesus accedes to the request to heal her daughter (Mk. 7:24-30; Mt. 15:21-8).

It is highly significant that Jesus displayed an uncharacteristically favourable attitude towards Samaritans (Lk. 9:51-6, 10:25-37, 17:11-19), and according to traditions preserved in John 4 ministered among them. Unlike many of his fellow-Jews ${ }^{34}$ he clearly accepted them as descendants of the former Northern tribes and as part of God's people. With Jesus the new age dawns. If his primary ministry was directed towards the reconstitution and revival of Israel (gathering in the lost sheep), we also see him anticipating both the eschatological reunion of North and South and the eschatological ingathering of the Gentiles.

${ }^{32}$ Cf. B. Sundkler, op. cit., 493-4; F. Hahn, op. cit., 36; E. Lohmeyer, Lord of the Temple (Richmond, John Knox 1962) 36-42. Lohmeyer cogently argues that 'what was previously only promise becomes now a reality drawing near; no, more than that, a reality that has drawn near: from the point of view of the nations of the earth the place for prayer destined by God for them is being made ready'.

${ }^{33}$ Cf. T.W. Manson, 'The Biblical Doctrine of Mission', 263-4: 'Jesus not only declares the Advent of the Reign of God, but he offers to men at once a share in its supernatural power'.

${ }^{34}$ See C.H.H. Scobie, in J.R. McKay, J.F. Miller (eds.), op. cit., 92-3. 


\section{Jews and Gentiles in the Early Church}

There is no disguising the fact that in the early days of the Christian Church there were serious differences of opinion regarding the grounds on which Gentiles could be accepted into the Christian community. Both Paul (Gal. 2:12) and Acts (11:2) refer in identical terms to 'the circumcision party' (hoi ek peritomés), a group usually labelled 'Judaisers' by modern scholars. It is important to note that those who belonged to this group did not object to Gentiles becoming members of the church. But their thinking followed the lines of incorporation: only through circumcision and acceptance of the full obligations of the Torah, i.e. only by becoming a proselyte and a naturalised Jew could a Gentile enter the Christian community. This was probably the view favoured initially by James, Peter and most of the Jerusalem community. Yet it was the view which lost out at the Council of Jerusalem of which we have account in Acts 15.

The view which was approved by the council, and which became the accepted New Testament view was that Gentiles are to be accepted as members of the people of God on the basis of faith in the proclamation of the gospel but without the requirements of circumcision or full Torah observance. In most people's minds this is the view associated with Paul; he certainly championed it, but he did not originate it. The Book of Acts goes out of its way to emphasise Peter's acceptance of Gentile converts before recounting any missionary outreach by Paul (Acts 10,11).35 Acts, however, also preserves traditions from the early years of the Church which make it clear that historically the Gentile mission originated neither with Paul nor with Peter but with the Hellenists. 36 As I have attempted to show elsewhere 37 it was this group with their more radical

${ }^{35}$ See D. Lotz, 'Peter's wider understanding of God's will: Acts 10: 34-48', IRM 77 (1988) 201-7.

${ }^{36}$ On the Hellenists see M. Simon, St Stephen and the Hellenists in the Primitive Church (London, Longmans Green 1958); R. Scroggs, 'The Earliest Hellenistic Christianity', in Religions in Antiquity, J. Neusner (ed.), (Leiden, Brill 1968) 176-206; M. Hengel, op. cit., 26-30; M. Hengel, 'Zwischen Jesus und Paulus: Die "Hellenisten", die "Sieben" und Stephanus (Apg 6,1-15; 7,54-8,3)', ZTK 72 (1975) 151-206.

37C.H.H. Scobie, Jesus or Paul? The Origin of the Universal Mission of the Christian Church', in From Jesus to Paul: Studies in Honour of 
views on temple and Torah which formed a vital link, both historically and theologically, between Jesus' message of the inbreaking of the Kingdom of God and the first major formulation of Christian thought by Paul. As Greek-speaking Jews, the Hellenists turned first to their own; after Stephen's death they 'travelled as far as Phoenicia and Cyprus and Antioch, speaking the word to none except Jews' (Acts 11:19). But then the Hellenist Philip broke new ground by taking the gospel to the Samaritans (Acts 8). 38 Remembering the pattern of Old Testament eschatological expectation we are not surprised to find the Hellenists taking the final logical step in Antioch and preaching 'to the Greeks' (regardless of whether we read hellenistas or hellenas in Acts 11:20, the context clearly indicates that Gentiles are meant). Antioch became the first major centre of the Gentile mission; from there Paul and Barnabas set out on the missionary journey narrated in Acts 13, 14 , and from there they went up to Jerusalem to the council which was to give the green light to the Gentile mission.

\section{The Theological Basis of the New Testament View}

The understanding of the relation between Israel and the nations practised by the Hellenists and championed by Paul was not based on the historical concept of incorporation, but on the eschatological concept of the ingathering of the Gentiles. One cannot, however, in this connection, interpret the evidence simply in terms of a promise-fulfilment scheme. The new reality of the Christ Event exceeds the expectations of the Old Testament and even to some degree reverses them. Biblical Theology is frequently a theology of surprise! This becomes clear when the New Testament developments are seen in the light of the three reasons advanced earlier for the lack of any active missionary outreach in the Old Testament.

(1) Firstly, in the Old Testament the ingathering of the Gentiles is an eschatological event; there is no outreach in the present because the Gentiles will find their place in God's purposes only at the last day. The Judaisers may well have

Francis Wright Beare, P. Richardson, J.C. Hurd (eds.), (Waterloo, Wilfred Laurier University Press 1984) 47-60.

${ }^{38}$ On the early Christian mission to the Samaritans see C.H.H. Scobie, 'The Origins and Development of Samaritan Christianity', NTS 19 (1972-73) 390-414. 
subscribed to this view. But the central affirmation of the New Testament, paradoxical though it may seem, is that with the Christ Event the New Order has already dawned. The Old Testament promises are in process of being fulfilled. Christians 'are living in an interim period which already belongs to the end, and yet still forms part of "this present age"'.39 If the final victory still lies in the future, nevertheless God's reign has already been inaugurated. Thus the time for the ingathering of the Gentiles is now, even though this may only be fully accomplished at the final consummation. God's concern for the whole created order is now fully manifest.

It is a probable suggestion that the Hellenists were among the first to grasp this vital theological truth, and if we ask what convinced them that the new age had dawned an important part of the answer must surely be their understanding of Jesus' resurrection and their experience of the Holy Spirit, the resurrection and the gift of the Spirit being major marks of the new age. 40

Despite the widely varying treatments of the theme in the various 'theologies' of the New Testament an underlying unity of thought is visible.

In Matthew41 the emphasis lies on the 'Great Commission' which climaxes the Gospel (Mt. 28:18-20). Whatever we think about the basis of this saying, ${ }^{2}$ theologically what is significant is that the command is not ascribed to the historical Jesus, but to the risen Christ. It is the completion of the Christ Event which signals the inauguration

${ }^{39} \mathrm{O}$. Cullmann, 'Eschatology and Missions in the New Testament', op. cit., G.H. Anderson, 45. Cf. T.W. Manson, 'Mission and Eschatology', IRM 42 (1953) 390.

${ }^{40}$ See J. Hempel, op. cit., 271. Cf. B.F. Meyer, op. cit., 181, who notes Stephen's reference to the Son of Man (Acts 7:56) and Philip's reference to the Servant (Acts 8:32-5) as significant allusions to sources which strike the note of universalism.

${ }^{41}$ On Matthew see F. Hahn, op. cit., 120-8; D. Senior, C. Stuhlmueller, op. cit., 233-54.

42See B.J. Hubbard, The Matthean Redaction of a Primitive Apostolic Commissioning: An Exegesis of Matthew 28:16-20 (Missoula, Scholars Press 1974); J. Matthey, 'The Great Commission according to Matthew', IRM 69 (1980) 161-73; M. Arias, 'Rethinking the Great Commission', TT 47 (1991) 410-18. For a discussion of the various forms of the Great Commission in all four Gospels see G.W. Peters, op. cit., 172-98. 
of the New Order thus the time for the ingathering of the Gentiles. 43

Mark ${ }^{44}$ anticipates the Gentile mission in a number of ways; particularly significant is the verdict of a Gentile centurion 'Truly this man was Son of God' (Mk. 15:39), a verdict which is only pronounced as Jesus dies on the cross.45 His version of the Great Commission occurs (in the Long Ending) in a post-resurrection context (Mk. 16:15).

Despite allegations to the contrary, John's Gospel 46 does have a strong sense of mission as the major theme of 'sending' shows. ${ }^{77}$ As the Father sent the Son (Jn. 7:28,29; 8:42), so the Son sends his disciples (Jn. 20:21) into the world (Jn. 17:18). The Father sends the Holy Spirit to aid the Church in its mission.48 If the 'certain Greeks' (hellenes tines) of John 12:20f. are to be seen as Gentiles their position in this Gospel is also deliberate: we are not actually told whether Jesus has direct contact with them, but verse 23 immediately declares, 'The

${ }^{43}$ D.R.A. Hare, D.J. Harrington, "Make Disciples of All the Gentiles" (Matthew 28:19)', CBQ 37 (1975) 359-69 argue that Jesus' command to 'make disciples of all the Gentiles' does not include the nation of Israel. But a strong case can be made that here Jews are still included among 'all the nations' (panta ta ethne)); see J. Meier, 'Gentiles or Nations in Matthew 28:19', CBQ 39 (1977) 94-102.

${ }^{44}$ On Mark see F. Hahn, op. cit., 111-20; D. Senior, C. Stuhlmueller, op. cit., 211-32.

${ }^{45} \mathrm{Cf}$. M. Kiddle, The Death of Jesus and the Admission of the Gentiles in St. Mark', JTS 35 (1934) 46: 'St Mark would have us see that the Gentiles could not be admitted before the death of Jesus'.

46 On the Johannine literature see F.N. Davey, The Gospel According to St. John and the Christian Mission', in G.H. Anderson, op. cit., 85-93; F. Hahn, op. cit., 152-63; D. Senior, C. Stuhlmueller, op. cit., 280-96. The most comprehensive study is T. Okure, The Johannine Approach to Mission: A Contextual Study of John 4:1-42 (Tübingen, J.C.B. Mohr 1988); see pp. 7-34 for 'A Survey of Major Approaches to Mission in John's Gospel in the Twentieth Century'.

${ }^{47}$ See J. Radermakers, 'Mission et apostolat dans l'Évangile johannique', in Studia Evangelica, II F.L. Cross (ed.), (Berlin, Akademie-Verlag 1964) 100-21; A.C. Winn, A Sense of Mission: Guidance from the Gospel of John (Philadelphia, Westminster 1981). On the concept of 'sending' see also F.M. DuBose, God Who Sends: A Fresh Quest for Biblical Mission (Nashville, Broadman 1983). P. May, op. cit., 27, claims that 'we can only think of the mission of the Church as an extension of God's sending of the Son and the Holy Spirit'.

${ }^{48}$ Cf. A.C. Winn, op. cit., 88-101. 
hour has come for the Son of Man to be glorified'. Here again, from the perspective of the Gospel, the Gentile mission lies in the future, upon the completion of the Christ event.

The Gentile mission is of course a major theme of Luke-Acts, ${ }^{49}$ but it is part of a larger pattern which is also in essence one of inaugurated eschatology. The three-fold expectation of the reconstitution of Israel, the reunion of North and South, and the ingathering of the Gentiles is anticipated in Luke's Gospel in its portrayal of Jesus as the one who fulfils God's promises to Israel (Lk. 1:54,55), who favours Samaritans, and who sends out the Seventy (the traditional number of the Gentile nations; Luke 10:1-12),50 though the command to preach to all nations is again post-resurrection (Lk. 24:47). The same three-fold pattern is used by Luke to structure the Book of Acts. Acts 1:8 forms a table of contents of the book: 51 You shall be my witnesses 52

1. in Jerusalem and in all Judea (=Acts 2-7, 9-12, the Jewish mission);

2. and Samaria (=Acts 8 , the Samaritan mission)

3. and to the end of the earth' (=Acts 13-28, the Gentile mission).

The crucial role of the Holy Spirit at each stage of the realisation of the eschatological pattern is emphasised by the prominence given to the Jewish Pentecost (Acts 2), the Samaritan Pentecost (Acts 8) and the Gentile Pentecost (Acts 10). 53

${ }^{49}$ See M. Kiddle, The admission of the Gentiles in St. Luke's Gospel and Acts', JTS 36 (1935) 160-73; F. Hahn, op. cit., 128-36; S.G. Wilson, The Gentiles and the Gentile Mission in Luke-Acts (Cambridge, CUP 1973); D. Senior, C. Stuhlmueller, op. cit., 255-79.

${ }^{50}$ This interpretation accords best with Lucan theology, but see S.G. Wilson, op. cit., 45-7.

${ }^{51}$ See P.H. Menoud, 'Le Plan des Actes des Apôtres', NTS 1 (1954-5) 4451.

${ }^{52}$ 'Witness' is an important concept, especially in Luke-Acts. The apostles are witnesses of the Christ Event (Lk. 24:48; Acts 1:21-2). On this theme see A. Trites, The New Testament Concept of Witness (Cambridge, CUP 1977).

${ }^{53}$ See M. Gourgues, 'Esprit des commencements et esprit des prolongements dans les Actes: note sur la "pentecôte des Samaritains" (Act., VIII, 5-25)', RB 93 (1986) 376-85. Gourgues suggests that while the Samaritans had individually received 'the quiet Spirit' (l'Esprit tranquille), what Peter and John conferred by the laying on of hands was 'the shattering Spirit' (l'Esprit fracassant), baptism 'in the Spirit', 
Paul can be mentioned here only briefly, 54 even though the Gentile mission plays a key role in his understanding of both his own call and ministry, 55 and of the message he is called to preach. He can certainly appeal to universal elements in a faith based on the Old Testament: 'Is God the God of the Jews only? Is he not the God of Gentiles also? Yes, of Gentiles also, since God is one' (Rom. 3:29,30).56 Yet it is clear that his distinctive theological position, and the place of the Gentiles in it, is based on an eschatology inaugurated by the Christ Event. The Christ Hymn of Philippians 2:6-11, which many scholars consider a quotation from an earlier Hellenistic Christian hymn, sings in turn of Christ's incarnation, servanthood and exaltation; but it is only with the reference to exaltation that the purpose of the total event is revealed in words which echo Isaiah's vision of the eschatological salvation of the Gentiles: 'that at the name of Jesus every knee should bow, in heaven and on earth and under the earth, and every tongue confess that Jesus Christ is Lord, to the glory of God the Father' (Phil. 2:10,11; cf. Is. 45:23).

For Paul, with the Christ Event 'the old has passed away, behold the new has come' (2 Cor. 5:17); 'now is the acceptable time, behold now is the day of salvation' (2 Cor. 6:2). The Christ Event is a sheer act of God's grace. Nothing that one can do can merit salvation or justification: God's grace can only be accepted as a gift through faith. Therefore in the new age that has dawned all mankind is on an equal footing, and the age-old promise is at last fulfilled:

The scripture, foreseeing that God would justify the Gentiles by faith, preached the gospel beforehand to Abraham, saying, 'In you shall all the nations be blessed'. So then, those who are people of faith are blessed with Abraham who had faith (Gal. 3:8,9).

parallel to that of Acts 2 and Acts 10, the 'Pentecosts' which signal a new stage in the mission.'

${ }^{54}$ On Paul see F. Hahn, op. cit., 95-110; C.H.H. Scobie, 'Paul and the Universal Mission of the Church', Crux 8 (1970-1) 10-7; D. Senior, C. Stuhlmueller, op. cit., 161-90; P. Bowers, 'Fulfilling the Gospel: The Scope of the Pauline Mission', JETS 30 (1987) 185-98.

${ }^{55}$ Paul saw himself as 'an apostle to the Gentiles' (Rom. 11:13), entrusted by God with a unique role in Heilsgeschichte. Cf. M. Hengel, op. cit., 17-24.

${ }^{56}$ Cf. D.G. Miller, 'Pauline Motives for the Christian Mission', in G.H. Anderson, op. cit., 72-24. 
The traditional eschatology to which Paul probably subscribed looked for the restitution of Israel, followed by the last days, with the Gentiles being gathered in at the final consummation. Paul's theology (born of his Damascus road encounter) and his experience (of the rejection of the gospel by most Jews, but the acceptance of it by a growing number of Gentiles) convinced him that now was the time of the ingathering of the Gentiles. However, he is not prepared to eliminate the Jews from a place in the purposes of God so in Romans 11:25-32 he arrives at a revision of the eschatological timetable: with the dawning of the new age now is the time for the gathering in of 'the full number of the Gentiles'; then 'all Israel will be saved'; then the end will come.

(2) The second reason for the lack of missionary outreach in the Old Testament was the fact that the ingathering of the Gentiles was not seen as the work of Israel; either the nations come of their own accord, or God himself gathers them in. Here the New Testament fulfilment is at the same time a reversal, though one which can claim some support from the Old Testament. The Gentile mission is willed by God, inaugurated by the Christ Event, and empowered by the Holy Spirit. But it does not depend on the Gentiles taking the initiative, rather it is undertaken by the new people of God.

The Church assumes the role of the Servant of Isaiah. According to Acts 13:46, 47, Paul justified his turning to the Gentiles by quoting the climax of the second Servant Song in Isaiah 49:6, and applying it to the Church (note the 'us' in v. 47a);

I have set you to be a light for the Gentiles, that you may bring salvation to the uttermost parts of the earth.

In the New Testament it is God's people, the Church, which proclaims the Gospel through preaching, though also through its life and example. 57

(3) This ties in with the third reason for the lack of outreach in the Old Testament. The eschatological expectation of the ingathering of the Gentiles was seen as involving the nations coming to Israel, not Israel going to the nations. Here the reversal is even more striking: the basically centripetal

57 See the helpful discussion in D. Senior, C. Stuhlmueller, op. cit., 3329, of 'The Modalities of Mission' in the NT. 
movement of the Old Testament is replaced by the centrifugal movement of the New Testament. The Old Testament 'nations shall come to your light' (Is. 60:3) is replaced by the New Testament ' $G o$ therefore and make disciples of all nations' (Mt. 28:19).

Instead of the nations coming in pilgrimage to Mount Zion, the message of the gospel is preached 'beginning in Jerusalem' (Lk. 24:47; cf. Acts 1:8). The city of Jerusalem plays an important role in Luke-Acts. 58 The Gospel opens and closes in the city. Acts opens in Jerusalem, and the Jerusalem Church has an authoritative position; nevertheless, Luke's second volume closes in Rome. Acts traces the spread of the Gospel from the Land of Israel to the lands of the nations, from the city of Jerusalem to the cities of the Graeco-Roman world.

\section{The Tribute of the Nations in the New Testament}

Although the centrifugal pattern dominates the New Testament it is interesting to note how one aspect of the centripetal Old Testament pattern, namely the expectation of the Tribute of the Nations is reflected in the New Testament. It is echoed in three quite different works-Matthew's Gospel, the letters of Paul and the Book of Revelation.

(1) In Matthew's infancy narrative the Magi, who come from the east, are clearly non-Jews, representatives of the nations. According to Matthew 2:11, 'opening their treasures, they offered him gifts, gold and frankincense and myrrh'; this clearly echoes the account of the tribute of the nations in Isaiah 60:6-"They shall bring gold and frankincense, and shall proclaim the praise of the Lord', with, of course, the significant addition of 'myrrh' 59 R.E. Brown recognises here 'an implicit citation' of Isaiah 60:6 (cf. Is. 60:1): the story reflects 'the Isaian description of the representatives of the nations who bring gold and frankincense to Jerusalem because the light and glory of the Lord has risen upon her. The Isaian citation helps to underline the Gentile character of the Magi.' Brown also notes a probable implicit citation of Psalm 72:10-11 which

${ }^{58}$ See S.G. Wilson, op. cit., 239-40.

${ }^{59}$ G.M.S. Prabhu, The Formula Quotations in the Infancy Narrative of Matthew: An Enquiry into the Tradition History of Mt 1-2 (Rome, Biblical Institute Press 1976), 275, argues that the reference to myrrh goes back to a pre-redactional source. 
mentions homage as well as gifts. 60 Thus although he preserves the clearest tradition of Jesus' forbidding any mission to non-Jews in his lifetime, at the beginning of his Gospel, with this account of the pilgrimage of the Gentiles and their bringing of tribute, Matthew anticipates the Great Commission with which his gospel closes. ${ }^{61}$

(2) Paul's collection of money which he organised among his Gentile churches also echoes this theme. Paul invested much time and effort in organising the collection (1 Cor. 16:1-4; 2 Cor. 8,9; Rom. 15:22-9). Acts 19:21, 20:1-21:16 supplements Paul's letters though it refers to the collection somewhat obliquely only in Acts 24:17 (though cf. Acts 24:26). While this was certainly intended both as an act of Christian charity and of Christian unity, it is hard to avoid the conclusion that as the various groups of Gentiles gathered the money and made their way to Jerusalem Paul must have seen this at least in part as a symbolic enactment of the eschatological tribute of the nations. K.F. Nickle has argued that the Gentile Christians represented by the delegates from the churches' went to Jerusalem, 'but not as seekers and petitioners of Israel'. 'They were coming as the true Israel of God, those already chosen by his grace to participate through faith in Christ in salvation'.62 Old Testament prophecy is once again given a new twist for while the tribute of the Gentiles is brought to Jerusalem, it is not brought to the Temple, but rather to 'the saints', to the community which now constitutes the eschatological temple'.63

\footnotetext{
${ }^{60}$ R.E. Brown, The Birth of the Messiah: A Commentary on the Infancy Narratives in Matthew and Luke (Garden City NY, Doubleday 1977). Brown suggests that the later Christian transformation of the magi into kings was based on a recognition of Matthew's allusion to Ps. 72:10-11; but it could equally well be derived from Is. 60:3. Brown also connects the magi with the story of Balaam, 'a seer from the east who saw the Davidic star rise'. Balaam is a Gentile, who came 'from the eastern mountains' (Nu. 23:7).

${ }^{61}$ A.M. Denis, 'L'adoration des mages vue par S. Matthieu', NRT 82 (1960) 32-9 shows how Mt. 2 is in harmony with the entire Gospel; the nations, i.e. Gentiles are present at both start and finish.

62K.F. Nickle, The Collection: A Study in Paul's Strategy (London, SCM 1966) 139.

${ }^{63}$ Cf. F. Hahn, op. cit., 109.
} 
(3) The third New Testament reference to the tribute of the nations serves to bring this study to an appropriate conclusion. The inauguration of the New Order through the Christ event lies at the heart of Biblical theology. But New Testament eschatology while inaugurated, is not yet fully realised. The Church lives between the 'already' and the 'not yet', for the final consummation still lies in the future. As the New Testament looks to the future on the one hand it sees the nations as powers which will continue to oppose God and his Kingdom. Yet on the other hand the period between now and the end is also the period when 'the gospel must first be preached to all nations' (Mk. 13:10; cf. Mt. 24:14, and also 2 Pet. 3:9).64 Finally, however, all nations come under God's judgment (Mt. 25:31-46; Rev. 20:11-5). In its magnificent series of visions of the end times the Book of Revelation looks towards the time when 'all nations shall come and worship thee' (Rev. 15:4). In Revelation 14:6 John sees an angel 'flying in midheaven, with an eternal gospel to proclaim to those who dwell on earth, to every nation and tribe and tongue and people'. The ingathering of the Gentiles, inaugurated by the Christ Event, begun in Jerusalem, carried out through the preaching of the gospel to all nations, reaches its culmination only at the final consummation.

The Holy City, New Jerusalem, says John, has no need of sun or moon 'for the glory of God is its light, and its lamp is the Lamb. By its light shall the nations walk; and the kings of the earth shall bring their glory into it. . they shall bring into it the glory and honour of the nations' (Rev. 21:23-6). Here is the final tribute of the nations. Though all that is unclean and false is excluded (Rev. 21:27), the kings of the earth bring their riches to Jerusalem. The passage is clearly based on Isaiah 60:1-11.65 All that is best and finest in human society and human culture is not abandoned, but is redeemed and brought in to share the life of the Kingdom of God. As Caird comments, 'Nothing from

${ }^{64}$ See J.W. Thompson, 'The Gentile Mission as an Eschatological Necessity', RQ 14 (1971) 18-27; O. Cullmann argues that what is 'restraining' the Antichrist in 2 Thes. 2:6-7 is the world-wide preaching of the gospel. See O. Cullmann, 'Le caractère eschatologique du devoir missionnaire et de la conscience apostolique de S. Paul: Étude sur le katechon(-on) de 2. Thess. 2:6-7', RHPR 16 (1936) 210-45.

${ }^{65} \mathrm{See} \mathrm{H}$. Kraft, Die Offenbarung des Johannes (Tübingen, J.C.B. Mohr, 1974), 273. 
the old order which has value in the sight of God is debarred from entry into the new. . . The treasure that men find laid up in heaven turns out to be the treasures and wealth of the nations, the best they have known and loved on earth redeemed of all imperfections and transfigured by the radiance of God'.66

Although the Old Testament theme of the eschatological Tribute of the Nations appears in these three quite different contexts nevertheless it may be claimed that, as is the case with all the inter-connected themes considered in this study, there is an underlying unity in the midst of diversity, for these references are all consistent with the overall Biblical Theology of Israel and the nations.

${ }^{66}$ G.B. Caird, The Revelation of St. John the Divine (London, Adam \& Charles Black 1966) 279. Cf. G.R. Beasley-Murray, The Book of Revelation (Grand Rapids, Eerdmans 1978) 328-9. Commenting on this text, O.R. Johnston, 'God and the Nations', ERT 1 (1977) 89, notes that John's vision 'is not that of a city of identical inhabitants, but rather a richly variegated community. . .' 